UDC 1/14:316

Karina OGANYAN

\title{
IDEOLOGICAL INTERSECTIONS OF PERSONALITY'S ANALYSIS IN ARMENIAN AND RUSSIAN SOCIAL-PHILOSOPHICAL THOUGHT
}

\begin{abstract}
This article presents ideological intersections of personality's analysis in the Armenian and Russian social-philosophical thought. In particular, between Russian sociologists of the end of XIX and the beginning of XX centuries (A.I.Stronin, N.I.Kareev) and the Armenian philosophers of IV - VIII centuries (Mesrop Mashtots, David Anhakht).

First are discussed Mesrop Mashtots' ideas about developing personality's cognitive abilities and socialpedagogical aspects of personality in A.I.Stronin's manuscript. The Russian and Armenian thinkers are united by aspiration to show education significance for personality's development. The second issue is the essence of practical and theoretical philosophy according to David Anhakht and theoretical and practical aspect of personality's analysis according to A.I.Stronin's conception. In total, the approaches of David Anhakht and A.I.Stronin agree in the opinion that the practical and theoretical aspects of personality's analysis are complementary to each other, by submitting a personality as harmoniously developed social creature. Thirdly, this paper deals with the David Anhakht's conception of human emotional world, ethic aspect of personality's analysis in the A.I.Stronin's manuscript and morality in personality's formation according to N.I.Kareev. The central idea that unites David Anhakht, A.I.Stronin and N.I.Kareev is the following: the main factor in personality's development is perfection by means of intellect and height of morality.
\end{abstract}

Keywords: personality, cognitive personality's abilities, social-pedagogical aspects of personality, personality's theory, the essence of practical and theoretical philosophy, theoretical and practical aspect in the personality's structure, human emotional world, ethic aspect of personality, morality in personality formation, Armenian philosophers and Russian sociologists.

The search of the ways of effective collaboration and integration between different national schools and directions of sociology acquires special value in the modern terms of globalization and geopolitics. In particular, special interest is presented by the goal of exposure of ideological contiguity points between the Armenian and Russian thinkers, since mutual relations of our countries have deep historical roots, that underline their ability to solve by mutual agreement any problem and strengthen the high level of Russian and Armenian co-operation.

Let us consider common features in the viewpoints of Russian sociologists of the end of XIX and the beginning of XX centuries (A.I.Stronin, N.I.Kareev) and the Armenian philosophers of IV - VIII centuries (Mesrop Mashtots, David Anhakht) regarding the problem of personality development. 
cognitive personality's ability and

social-pedagogical aspects of personality

in the A.I.Stronin's manuscript

Mesrop Mashtots considers human cognitive ability important in preventing and weakening social evil in society, "through trying to find out, by what methods and how man cognizes the surrounding him world, and by what consciousness he fights against the social evil, that emerged independently of him". (Gasparyan 2014: 210)

Environments cognition, according to Mesrop Mashtots is a prolonged process, and man after his birth does not have the opportunity directly to demonstrate his mental, cognitive abilities and capacities. They show up gradually, in parallel with the increase of man's body weight, due to instructions from the teachers abilities to recognize and study come to light.

Here the question is about developing individual's cognitive capacities, where a major role belongs to education and teacher, that fill man's spiritual world, according to his age and mental abilities. (Arevshatyan, Mirumyan 1991: 109)

Personality's aspiring to cognition and self-perfection was examined by the A.I.Stronin, the classic of Russian sociology, in his manuscript "Theory of personality". The "Theory of personality" is an historicalphilosophical and sociological work, where the A.I.Stronin's views are clearly positivistic. The manuscript's original is presented by five notebooks. In this work A.I.Stronin exposes the "program of personality's theory", presented by "philosophy of past", "philosophy of present" and "philosophy of future". (Stronin 2013: 132-176)

Analyzing A.I.Stronin's presentations about personality we educed the next aspects of her study: ethical,

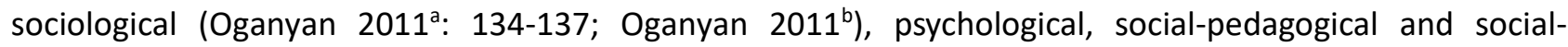
psychological.

We will analyze the socially-pedagogical aspect of her study in the context of comparison of A.I.Stronin's ideas with personality's viewpoint of Mesrop Mashtots.

The social-pedagogical aspect of A. Stronin's personality study is examined in the following two aspects: a) Disclosure of the personality-oriented technologies in education and the necessity of their application; (Stronin 1883: 12-13)

b) posing the problem of education quality (Ibid: 32 ).

A) Disclosure of the personality-oriented technologies in education and necessity of their application. A.I.Stronin asserts that the process of individualization in the education system opens before personality the possibility of original development, and this is the aim of education. The Russian sociologist considers that there is no necessity for examinations and transfers: "let every man put himself in the class, which should be adequate, otherwise school prefers itself to the student and sacrifices reality to ideals". (Ibid: L. 10)

The analysis of this problem brings A.I.Stronin, in our view, quite absurd and unjustified arguments: "The exams are necessary there and such, where and what cognition is required by practice and life. When you need the known specialist, then examine him, when you need a generally well-educated man - then examine him; and why to examine one, who will not ask any rights for specialty or universal education? Why you must examine a man that has to be a merchant, artisan, author, and scientist"? (Ibid) 
The educating process is the system, in that a significant place occupies the control of student's knowledge by means of tests, examinations. This verification form assists the exposure of a feed-back between students and teachers, allow estimating teaching quality and the level of students training. Thus, all students must undergo procedure of knowledge verification, regardless of giftedness degree, propensity to one or another type of activity.

B) Setting the quality of education issues. It draws our attention to the question that pedagogy is always concentrated on the content of education: the specificity of subjects, the number of hours taught. Thus, that problem of different pedagogical technologies application and shortage of pedagogical stuff - does not deserve due attention. According to A.I.Stronin's opinion, the problem - "how to teach and who to teach"? is most the most essential one.

Thus, the pedagogical aspect of personality's study is considered in the frame of humanistic paradigm, where primary objective of pedagogical process - to assist developing man's abilities, his personality development, his spiritual growth, morality, self-realization.

From the pedagogical point of view personality, for A.I.Stronin, is the spiritually developed moral man apt at self-development and self-perfection.

The Russian and Armenian thinkers are united by aspiration to show education significance for personality's development.

2. David Anhakht on the essence of practical and theoretical philosophy and theoretical and practical aspects of personality's analysis in the personality's structure according to A.I.Stronin

David Anhakht, analyzing and discussing the theme free will, and, and, in particular, the consistent implementation of human social norms, comes to the conclusion that the necessity to solve these problems depends on that, what place in the system of sciences is given to ethics, moral and problems of personality's socialization. And for this reason, due to the creation of the Armenian alphabet appeared the possibility considering the "requirement of legal citizens' education". (Mkhitaryan 1983: 248-249)

In this context, practical philosophy, according to David Anakht, embracing man's desires, selectivity, and consent shows, how an individual makes a choice to satisfy his desires, and, reasonably organizing his behavior, how he can avoid passions and emotions. All of these ideas are arming people with the help of the theoretical part of philosophy that continuously takes into account his thoughts and opinions, providing intellectual power.

As a result, theoretical and practical parts of philosophy, according to David Anhakht, serve not only to the development of sociological thought but also to its improvement, as far as "in the process of moralization of public life areas all kinds of relationships can't be imagined without truth and without good will of man". (Gasparyan 2014: 215)

In this regard, we have identified some of the points of intersection with the vision of the structure of personality in A.I.Stronin theory presented by means of analysis of theoretical and practical aspects of its study.

In the center of A.I.Stronin's conception of the structure of personality there is an aesthetic component of the development of the personality as an ideal form of a harmonious human (see. Fig. 1). One of such ideal 
forming terms are the external feelings, expressed by five senses: tactile, sense of smell, hearing, sight, as well as by internal feelings: love, hatred, fear et al.

The theoretical aspect of personality's study, according to A.I.Stronin, are expressed in three parameters: psycho-physiological functions and organic necessities; religious consciousness and behavior; status and social functions-roles.

Thus, the theoretical aspect, according to A.I.Stronin, implies the contemplative, intellectual personality's activity, expressed by means of co-operation of three personality's sides: man as psychophysiological creature, religious man, and social man.

The practical aspect of personality's study is presented by the system of value orientations of the personality comprising three blocks: selfish personality traits; moral qualities and values of goodness and justice; material, economic values and interests. Thus, the practical aspect is examined by A.I.Stronin in three personality's types: selfish man, moral man and economic man.

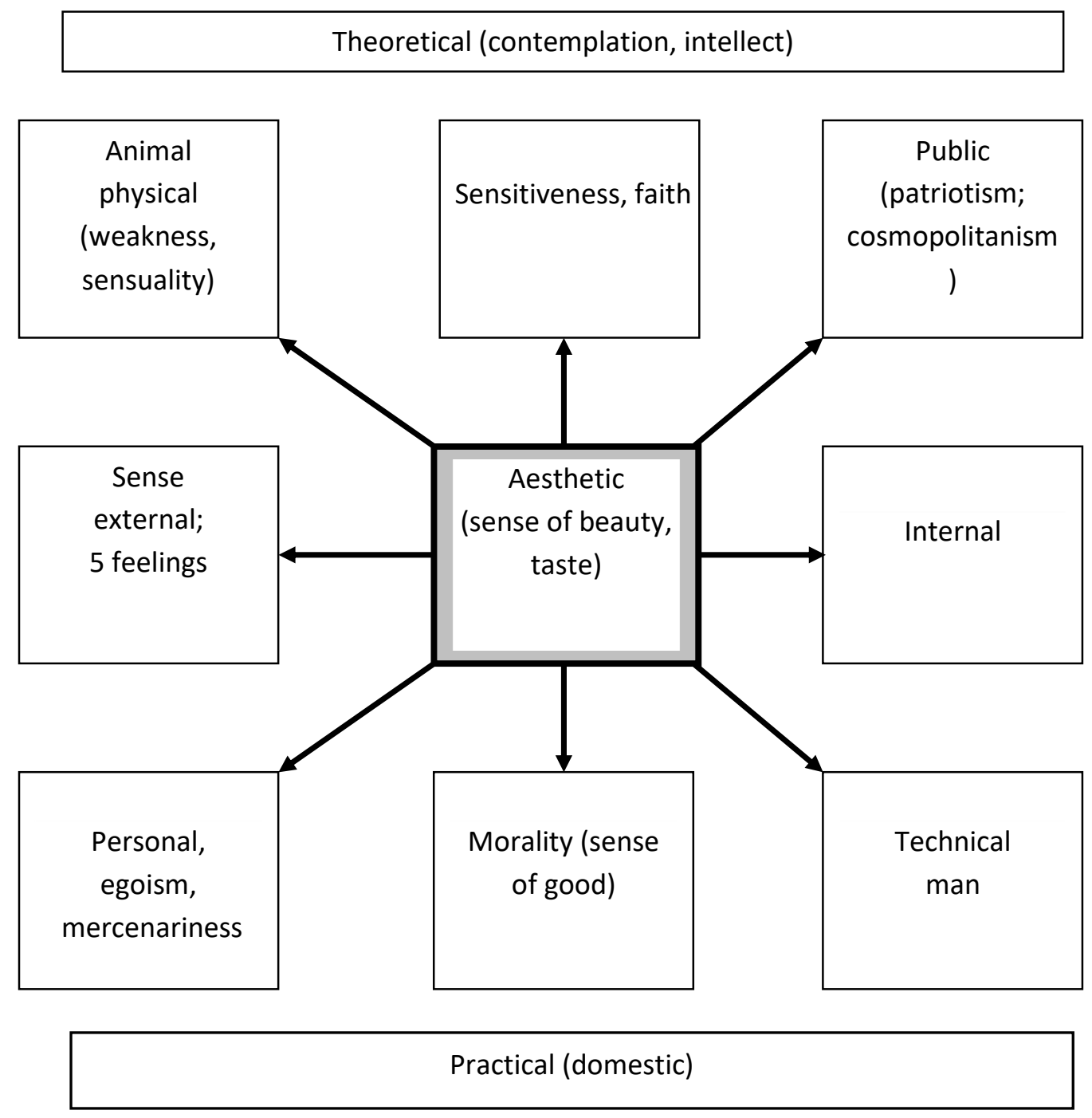

Figure 1. Personality's structure by A.I.Stronin 
A personality's structure in the A.I.Stronin's theory includes totality of objective and subjecttive personal properties, arising up and functioning in the process of his various activities, under influence of those communities and associations, into which the person is involved.

To sum up, David Anhakht and A.I.Stronin agree that the practical and theoretical aspects of identity analysis are complementary, representing the person as a social being developed harmoniously.

3. Analysis of examples of human emotional world in David Anhakht's conception, ethic aspect of personality in the A.I.Stronin's manuscript and morality in personality's forming according to N.I.Kareev

David Anhakht, according to his personality's analysis approach, considers that the source of human power is comprised by his feelings and intellect. He "often makes examples from man's emotional world, in order that to ground the positive and negative lines of rational and inefficient behavior. He analyzed laughter and desire, anger and sorrow thoroughly" (Tutundzhyan 1980: 242), characterizing the psychological side of human emotions, and also analyzing categories of logic.

A.I.Stronin, as a representative of Russian sociology organic school, in this context, pays considerable attention to morality in the analysis of the personality.

The ethic aspect of personality's study is presented by the analysis of the following points:

a) the interdependence of fear and moral quality - the lie (Ibid: 10, T. 1);

b) interdependence of external and internal displays of personality's qualities (Ibid: 1, T. 2);

c) features of moral qualities and personality's feelings displayed in public relations (Ibid: 21, T. 2);

d) moral qualities characteristic for different social strata (Ibid: 22-23, T. 2);

e) features displaying the content of types of love (Ibid: 23-24, T. 2; 23-24, T. 4).

B) Interdependence of external and internal displays of personality's qualities. There is close intercommunication between personality traits of character and their external expression showing up in the nonverbal behavior. Smile well only clean and honest people, unclean and evil people can't smile clearly, a person's smile is always distorted by his dominating trait. It's hard not to agree with A.I.Stronin, since in the mimicry of the individual in many ways is reflected his inner world, particular worldview. A pragmatic person often would smile rather arrogantly, cold-bloodedly, slyly and in the same manner he would communicate with the people around him. Such description is got by business representatives in modern society. Sincerity, kindness, openness manifests itself in facial expressions and behavior of an honest and decent man, as he is ready to share all he has got with surrounding people and has nothing to hide. Such qualities, in contrast to businessmen, you can meet in people involved in the creative and intellectual work.

Nevertheless, if we talk about the signs of nonverbal behavior, then one factor is not enough, that it was possible to do sound conclusions about man's character, negative or positive parties of his behavior. It is necessary to take into account the whole complex of nonverbal behavior different displays, such as: gestures, poses, clothing colors, in order that to form the certain socially-psychological personality's portrait.

The idea of morality meaningfulness in personality's development is examined in the works of N.I.Kareev - a representative of Russian sociological-psychological school. 
The expansion and multi-faceted interpretation of the moral personality concept is proposed in the N.I.Kareev's sociological conception. This concept N.I.Kareev considers by analyzing the relationship between personality and individuality, as well as by discussing the nature of social activities. (Oganyan 2013: 1250-1254)

In both his writings: "Thoughts about the morality's basics" and "Thoughts on the essence of social activity" N.I.Kareev. considers the individual person, and concludes that all of the difference lies in the fact that in one case the question is about the individual as a moral person, and in another case - about the individual as a public figure; in the first case, a moral person is considered in his relationship to himself, and in particular in the relationship to other people, in the second case is considered only individual's social activities, his public life rather than private (Kareev 1895; Kareev 1901).

The spiritual development of the person's consciousness is a constant creativity and improvement of his moral and social ideal. N.I.Kareev argued that a person can't become a person, not having learned of his social nature, and a person can't acquire independent existence, without becoming a personality. The essence of a moral person by N.IKareyev is as follows: individuality (ethics emerges as one of its sides) is the center of the personality, its inner core.

This idea unites David Anhakht, A.I.Stronin and N.I.Kareev: the main factor in personality's development is perfection by means of intellect and height of morality.

\section{Conclusions}

The analysis for identifying the ideological intersections between the Armenian philosophers and Russian sociologists showed that this topic requires further development, in-depth study of the specifics of the individual and personality in the works of Armenian thinkers.

Special consideration is required by ideological intersections between ideas of Armenian subjectivist sociologists, in particular E.Frangyan and ideas of the first generation of Russian subjectivist sociology P. L.Lavrov, N.Mikhailovsky, S.N.Yuzhakov and the second generation.

The presented Russian and Armenian thinkers are united by one - all of them examine personality as social creature, aspiring to intellectual and moral self-perfection.

\section{REFERENSES}

Arevshatyan, S., Mirumyan, K. (1991). Istoriya armyanskoi filosofii. Drevnii period i rannee Srednevekov'e (History of Armenian philosophy. Ancient period and early middle ages).

Gasparyan, Yu.A. (2014). Razvitie sotsiologi eskoi mysli v Armenii v IV - VIII vv. (Development of sociological thought in Armenia in IV - VIII centures). Yerevan: Limush.

Kareev, N.I. (1895). Mysli ob osnovakh nravstvennosti (Ideas about morality's bases). SPb.

Kareev, N.I. (1901). Mysli o sushchnosti obshchestvennoi deyatel'nosti (Ideas about public activity essence). SPb.

Mkhitaryan, G. (1983). Sotsial'nye vzglyady Davida Anakhta. (David Anhakht's social views). Materialy nauchnoi konferentsii, posvyashch. 1500-letiyu so dnya rozhdeniya. Yerevan. 
Oganyan, K.K. (2013). Istoriko-sotsiologicheskii analiz nravstvennoi lichnosti v kontseptsii N.I.Kareeva I A.I.Stronina (A historical-sociological analysis of moral personality in N.Kareev and A.Stronin conceptions). No 8, chast' 5, pp. 1250-1254.

Oganyan, K.K. $\left(2011^{\mathrm{a}}\right)$. Analiz faktorov uspeshnoi sotsializatsii lichnosti v rukopisi Stronina A.I. Teoriya lichnosti I sovremennost' (An analysis of successful personality's socialization factors in A.Stronin's manuscript of "Personality's Theory"). Shestye Kovalevskie chtenniya. Materialy nauchno-prakticheskoi konferentsii 11-12 noyabrya 2011 goda. Otv. Red. Yu. V.Asochakov. SPb. pp. 134-137.

Oganyan, K.K. $\left(2011^{\text {b}}\right)$. Sociologicheskii analiz lichnosti v rukopisi A.I.Stronina Teoriya lichnosti I sovremennosti (A sociological personality's analysis in the A.Stronin's manuscript “Personality's theory" and contemporary). Elektronnyi nauchni zhurnal Sovremennye problem nauki i obrazovaniya. No 5. URL:

http://www.science-education.ru/ru/ article/view?id=4806(dataobrashche niya: 30.06.2016).

Stronin, A.I. (1883). Teoriya lichnosti (Personality's theory). Otdel rukopisei Rossiiskoi nacional'noi biblioteki g.Sankt-Peterburg. F. 752, D. 13, L. 10. No 28.

Stronin, A.I. (2013). Teoriya lichnosti (A personality's theory) (po materialam rukopisi). Avt.-sost. Nauchnogo issledovaniya K.K.Oganyan. 2-e izd., dop. I pererab. Moskva. INFRA-M (Seriya: Nauchnaya mysl').

Tutundzhyan, G. (1980). Psikhologicheskie vzglyady Davida Anakhta (David Anhakht's psychological views). Materialy nauchnoi konferentsii, posvyashch. 1500-letiyu so dnya rozhdeniya Davida Anakhta. 